\title{
The Role of the City in the Formation of Spanish American Dialect Zones
}

(C) John M. Lipski

The Pennsylvania State University

E-mail - jlipski@psu.edu

\section{Introduction}

Five hundred years ago, a rather homogeneous variety of Spanish spoken by a few thousand settlers was scattered across two continents. Although many regional languages were spoken in fifteenth century Spain (and most are still spoken even today), only Castilian made its way to the Americas, in itself a remarkable development. More remarkable still is the regional and social variation that characterizes modern Latin American Spanish; some of the differences among Latin American Spanish dialects are reflected in dialect divisions in contemporary Spain, while others are unprecedented across the Atlantic. Some practical examples of this diversity are:

- At least in some part of every Latin American nation except for Puerto Rico and the Dominican Republic, the pronoun vos is used instead of or in competition with tú for familiar usage; at least six different sets of verbal endings accompany voseo usage. The pronoun vos is not used in any variety of Peninsular Spanish, nor has it been used for more than three hundred years.

- In the Caribbean, much of Central America, the entire Pacific coast of South America, the Rio de la Plata nations, and a few areas of Mexico, syllable and word-final consonants are weakened or lost, especially final [s]. In interior highland areas of Mexico, Guatemala, and the Andean zone of South America, final consonants are tenaciously retained, while unstressed vowels are often lost, thus making quinientas personas sound like quinients prsons. Such vowel-weak pronunciation is nonexistent in Spain, while loss of final consonants is found in many parts of that country.

- In the Antilles (Cuba, Puerto Rico, the Dominican Republic), and sporadically in other Caribbean nations, non-inverted questions of the sort ¿Qué tú quieres? and ¿Dónde usted vive? are common, while being virtually unknown in other Latin American dialects. In Spain, such constructions are almost never heard, except occasionally in Galicia (under the influence 
of Galician), and the Canary Islands (where the Galician influence was once prominent).

- In the same Caribbean Spanish dialects and a few others, normative expressions with the subjunctive are replaced by the combination SUBJECT PRONOUN + INFINITIVE, sounding suspiciously like "errors" committed by English speakers learning Spanish: antes de yo venir aquí, para nosotros llegar al centro, etc. This construction is only sporadically attested in Spain, typically in Galician-influenced areas.

- Direct object pronouns exhibit great variety when accompanying direct object nouns and pronouns. Thus, while all Spanish dialects allow (even require) lo conozco a él, Southern Cone dialects also allow lo conozco a Juan. Andean and some other dialects further allow lo conozco el museo, with a non-animate direct object. Among Andean speakers for whom Spanish is a second language, non-agreeing lo may also be used: lo veo las casas. In Spain, only pronominal direct objects allow doubled clitic pronouns: le conozco a él.

\section{The sources of dialect differentiation}

In accounting for dialect diversification in Latin American Spanish, three main factors come into play. The first is the Peninsular roots of Latin American Spanish, meaning the varieties spoken by Spanish settlers from all over peninsular and insular Spain over a period of more than four centuries. The second is contact with other languages, these being principally the indigenous languages of the Americas spoken in the major Spanish colonies, but also African languages spoken by hundreds of thousands of slaves, and to a lesser extent languages of voluntary immigration in later centuries, mainly Italian, English, Chinese, and Afro-European creole languages of the Caribbean, such as Haitian Creole, Jamaican Creole, and Papiamentu (Lipski 1996, 1999a). The third factor is linguistic drift, spontaneous changes which occur in the absence of standardizing forces of a large metropolis, and which even in the most literate societies result in the inevitable and inexorable change of all languages across time. All three factors had their impact at one point or another, but central to all three themes is the question of how much linguistic influence a given group of individuals exerted on the Spanish language at particular times. Put in other words, how many speakers of one language or dialect are needed to leave a permanent imprint on the evolving Spanish American varieties? Is the lemma 'first is best' the appropriate slogan, or is 'safety in numbers' (or, in the case of involuntary servitude, 'misery loves company') a more fitting label? Like the questions asked by journalists and detectives, the 'who,' 'where,' 'why,' and 'when' must be determined in order to account for the 'what' of 
language diversification. The answers to all or even most of these questions would totally derail these proceedings, so in the spirit of the focus on the city, la ciudad, a cidade, the remaining remarks will focus on the catalytic effect that emerging cities in Spanish America exerted on regional varieties of Spanish, which ultimately spread far beyond the pale of the cities to become regional, national, and transnational standards.

\section{The dichotomy DEMOGRAPHIC STRENGTH vs. CHRONOLOGICAL PRIMACY}

In searching for the roots of Latin American Spanish dialectal variation, proposals have grouped around two opposing viewpoints, as regards the relative importance of demographic strength versus chronological primacy. The first proposal is that uniquely defining characteristics of a given dialect are directly correlated with the demographic proportions of groups-be they speakers of other varieties of Spanish or other languages-assumed to have contributed the features in question. For example, a high percentage of Basque settlers in a colony's history might account for local Spanish traits not otherwise derivable from the early colonial mix, while the fact that Costa Rica was largely populated by small farmers from Andalusia during most of its colonial history could account for features of Costa Rican Spanish. Such claims must confront obvious contradictions within the data of Latin American Spanish; thus, while Basque influence has been suggested for retention of the phoneme /8/ (written II) in Paraguayan Spanish (e.g. by Granda 1979), other traits of Paraguayan Spanish, such as the weak aspirated pronunciation of final /s/, stand in sharp contrast to the clipped Spanish of the Basque Country. Moreover, Basque influence was even stronger in colonial Venezuela, where the Compañía Guipuzcoana was once the major economic force, and yet Venezuelan Spanish bears absolutely no resemblance to the Spanish of the Basque region of Spain. New Mexico was also settled largely by Basques (including the founder of the first colony, Juan de Oñate), but New Mexican Spanish is vastly different than any variety heard in northern Spain. Similarly, although the early presence of Andalusian farmers is undisputed for Costa Rica, central Costa Rican Spanish is among the least 'Andalusian-like' varieties of Latin American Spanish. In 1898, on the eve of the Spanish-American War, nearly half of the Cuban population had been born in insular or peninsular Spain, and nearly $25 \%$ of the Cuban population came from areas of Spain where final /s/ resists effacement and where the phoneme /2/ (zeta) is opposed to /s/, and yet this massively un-Cuban speech community left absolutely no trace on subsequent incarnations of Cuban Spanish. On the other hand, the arrival of tens of thousands of Italian immigrants to Buenos Aires and 
Montevideo beginning at the turn of the twentieth century left indelible influences not only on the vocabulary of Rio Platense Spanish, but also in the pronunciation, particularly regarding intonation patterns.

The opposing postulate holds that the first settlers-the 'founders'exercised a permanent influence on the subsequent development of the dialect in a fashion far out of proportion to their demographic strength, continuing on past the time when descendents of the original founders enjoyed any special prominence. This debate is played out against the backdrop of the rural-urban axis, with many distinctive dialectal traits apparently stemming from rural sources, while-it can be argued-the consolidation of dialect zones, the effective operation of dialect leveling, and the most telling instances of contact-induced language change, are all the product of cities. In the following remarks, we shall explore the many crossroads which mark the expansion and diversification of Latin American Spanish (and along the way, the nature of Spanish and Portuguese dialects in other parts of the world), and examine the changing role of the city as a catalyst of linguistic evolution.

\section{The 'founder principle' and the 'Antillean period'}

Of the theories seeking to establish the roots of Latin American Spanish in the speech of the earliest settlers, the most influential is the so-called 'Antillean period' from 1493-1519 (e.g. by Boyd-Bowman 1956; Catalán 1958; Guitarte 1980; Rosenblat 1977: 20; cf. also Lockhart and Schwartz 1983: chap. 3). During this period Spain consolidated its settlements on Hispaniola and Cuba, and launched expeditions to Central and South America. Santo Domingo was the point of departure for the first expeditions to Puerto Rico, Cuba, Trinidad, Jamaica, Darien, the Caribbean coast of Venezuela and Colombia, and the Yucatan (Rosenblat 1977: 20). Cuba was the launching place for expeditions to the coast of Mexico, while the first explorations of Peru began in the Darien, along the coast of what is now northeastern Panama, near the Colombian border. According to one line of thought, the Andalusian influence became decisive during the early decades of the sixteenth century, when the Spanish settlements in the New World were entirely sustained by maritime contact with Europe. Successive arrivals who participated in exploration and settlement of the mainland would, it is claimed, be immersed in the prevailing speech patterns of the American insular settlements, and would in turn carry this form of speech to colonies established on the mainland. Although Spanish trade with mainland colonies soon bypassed the Antilles, except for purposes of 
reprovisionment, the seeds of 'Andalusian-American' Spanish would have been sown.

Boyd-Bowman's 'Antillean period' theory is an instantiation of what Mufwene (1996a, 1996b) calls the 'Founder Principle,' a hypothesis which he has applied to the origin and development of creole languages, in which it is claimed that

Structural features of creoles have been predetermined to a large extent ... by characteristics of the vernaculars spoken by the populations which founded the colonies in which they developed. European colonies often started with large proportions of indentured servants and other low-class employees of colonial companies, thus by speakers of nonstandard varieties of the creoles' lexifiers' (Mufwene 1996a:84).

The Founder Principle is modeled after population genetics, in which an originally recessive or disadvantageous trait can spread in a colony due to (1) mutation, (2) changes in the ecological conditions, and (3) a significant proportional increase in the carriers of the particular trait. Unlike Boyd-Bowman's theory for the emergence of (Antillean) Latin American Spanish, the Founder Principle does not ascribe any special prestige to the creators of a creole language; indeed, they often represent the lowest social classes and marginalized groups, whose very marginality in a colonial setting gives precedence to their erstwhile non-prestigious speech forms, propelling them into a new linguistic standard. Both approaches coincide in attributing virtually all major traits of a new language or dialect cluster to the earliest speakers, transplanted from a metropolis or from peripheral zones where their languages and dialectal traits come together for the first time.

Let us evaluate the feasibility of a hypothesis such as the Founder Principle for the formative period of Latin American Spanish dialects. It is often stated that Latin American Spanish is 'Andalusian' in character, as opposed to 'Castilian,' but when comparisons are made with the contemporary dialects of Spain, only the Spanish dialects of the Caribbean Basin truly sound 'Andalusian' in the modern sense, while highland dialects, e.g. of central Mexico, Colombia, Peru, and Bolivia in many ways resemble 'Castilian' Spanish. Modern Andalusian Spanish is characterized by the extreme reduction of syllable-final consonants, leading to massive elision of preconsonantal and word-final /s/, as well as regular loss of word-final $/ / /$ and $/ \mathrm{r} /$. Wordfinal $/ \mathrm{n} /$ is routinely velarized, preconsonantal $/ / /$ and $/ \mathrm{r} /$ are frequently neutralized, usually in favor of [r], and intervocalic and word-final /d/ is usually lost. In Seville and its environs, /.../ receives a fricative 
pronunciation [š], and /y/ may receive a groove fricative realization similar to [ž]. It is this striking phonetic profile which most immediately characterizes Andalusian dialects, although there are other areas of Spain which exhibit the same features, albeit in differing proportions. These features are clearly not present in all or even most Latin American Spanish dialects; more importantly, most were not present in Andalusian Spanish at the time of the early colonization of the Americas. Velarization of $/ \mathrm{n} /$ arguably had begun by the turn of the sixteenth century (Boyd-Bowman 1975), while erosion of other syllable- and word-final consonants was only beginning to appear (Frago García 1983, Lipski 1995, Torreblanca 1989).[1]

Spanish continued to evolve in Latin America whether or not in contact with European innovations. All dialects of Latin American Spanish acquired most of the major linguistic innovations that occurred in Spain at least through the end of the seventeenth century, and some more recent Peninsular phenomena were also transferred to Latin America. Among the pan-Hispanic changes occurring well past the first century of Spanish-American colonization, are the following.

(1) In 1492, Spanish contained six sibilants, voiced and voiceless: /s/ (ss), /z/ (s), /ts/ (c), / /dz/ (z), /š/ (x), /ž/ (g/j). /s/ and /z/ were apicoalveolar, like contemporary Castilian /s/. There is some indication that merger of the alveolar fricatives and affricates, the precursor of seseo, was already beginning in Andalusia by the end of the fifteenth century, but the change was not complete (Catalán 1956-7). In no Spanish dialect had devoicing of the voiced sibilants even begun. Devoicing, when it did come, originated in extreme northern Spain, in rural regions of Old Castille. By the middle of the sixteenth century, devoicing of sibilants was accepted in the New Castilian court at Toledo, but was not yet the norm in Andalusia. Sephardic Spanish, dislodged from contact with Peninsular dialects by the early sixteenth century, has merged $/ \mathrm{s} /$ and $/ \mathrm{t} /, / \mathrm{z} /$ and $/ \mathrm{d}^{\mathrm{z}} /$, but retains the voicing distinction. In Latin America, early Spanish borrowings into Nahuatl, Quechua and Guaraní verify that Spanish colonists still maintained the difference in voicing. Within Spain, devoicing of $/ z /$ and $/ \mathrm{d}^{z} /$ was complete by the end of the sixteenth century (Catalán 1957), even in Andalusia. If Latin American Spanish had received an Andalusian imprint during the 'Antillean period,' we should expect a voicing distinction between /s/ and /z/ to have remained indefinitely. Instead, Latin American Spanish kept pace with both Castile and Andalusia in devoicing all sibilants, at approximately the same time as was occurring in Spain. In the New World and in western Andalusia, all the sibilants fell together to $/ \mathrm{s} /$. In the remainder of Spain, the reflex of $/ \mathrm{t} \mathrm{s} /$ $/ \mathrm{d}^{\mathrm{z}} /$ became an interdental fricative $/ 2 /$. 
(2) As another part of the general devoicing process, Spanish /š / and $|z ̌|$ merged to a voiceless fricative, which later velarized to $|x|$, with the change being complete by the middle of the seventeenth century (Lapesa 1980:379). Early borrowings into Native American languages give proof that /š/ was still a prepalatal fricative during the first century of Spanish settlement in the New World, but it too followed the dialects of Spain. The guttural Castilian fricative [P] never emerged in Latin America (it appears to be a subsequent innovation in northern Spain), but the variety of posterior fricatives which represent $/ x /$ in Spanish America is not a simple transplantation of the weak western Andalusian $/ \mathrm{x} />$ [h]

(3) Nebrija's grammar of 1492 and Valdés's Diálogo de la lengua of 1529 indicate that /b/ and / $/$ were still separate phonemes in Spain during the 'Antillean period' of Latin American settlement. Spanish words taken into Native American languages during the sixteenth century reflect this difference. $/ \mathrm{b} /$ and $/ \mathrm{v} /$ subsequently merged in all Peninsular and Latin American dialects.

(4) At the time of the first Spanish settlements in the Americas, the formal pronouns usted and ustedes had not yet emerged. In Spain, these pronouns did not come into general use until the end of the seventeenth century; Latin American Spanish acquired the pronouns at the same time. At the end of the fifteenth century, vos and tú still vied with one another as both formal and familiar pronouns, with vos still frequently used with plural reference. Vos subsequently disappeared from the dialects of Spain, while being retained in much of Latin America. However, most major Latin American cities and surrounding areas adopted the Peninsular preference for tú as the familiar pronoun; Maracaibo, Buenos Aires, and Montevideo, as well as the relatively small cities of Central America, are noteworthy exceptions.

The preceding survey amply demonstrates that early sixteenth century Spanish of the 'Antillean period,' or even the Spanish brought to colonies founded throughout the seventeenth century, is vastly different from all modern varieties of Spanish, in Spain and Latin America, thus dealing a mortal blow to the 'founder principle' as applied to Caribbean-and by extension other-dialects of Spanish. Indeed, the only surviving variety of Spanish which closely resembles early sixteenth century Spanish is Sephardic or Judeo-Spanish (known in the vernacular as judezmo or, in its written form, as ladino, spoken by descendents of Sephardic Jews expelled from Spain beginning in 1492, who maintained their language in isolated communities in eastern Europe, the Middle East, and North Africa, isolated from innovations that spread to the remainder of the Spanish- 
speaking world. Sephardic Spanish is a reasonable approximation to what Caribbean Spanish might actually be like if the 'founder principle' or 'Antillean period' models were viable hypotheses for the formation of modern Latin American Spanish dialects.

Models of dialect formation which limit the formative period to the first half or even full century of colonial settlement are unrealistic, for incontrovertible evidence exists that linguistic cross-fertilization between Spain and Latin America extended over several centuries. In any nation arising from colonization, the speech and cultural patterns of the first settlers retains a nostalgic significance that transcends any objective contribution that this group might have made. In reconstructing the true history of a nation, colonial heroes assume larger-than-life proportions, and the spirit of the original colonists is seen embodied in the current population. These sentimental issues rarely hold up under serious linguistic scrutiny, and in truth Latin American Spanish is the product not only of its first settlers but of the totality of the population, immigrants and natives alike.

\section{In search of alternative models: the role of the city}

If the crucial defining traits of contemporary Latin American Spanish were not forged during the early sixteenth century as suggested by the 'Founder Principle,' then attention must be shifted to later events, from the late sixteenth century to the first decades of the twentieth century. It will be claimed that in the development of distinctive dialects of Latin American Spanish, the city played a decisive role, first in absorbing and concentrating influences arriving from outside, and subsequently in diffusing and dispersing urban dialects across ever-widening regions. It is the case, for example, that although indigenous populations in Spanish America often outnumbered Spanish settlers by factors of several thousand to one, the Spanish interlanguages as spoken by indigenous bilinguals only began to have a permanent effect on regional Spanish dialects when they became absorbed into the urban setting. Similarly, the presence of hundreds of thousands of African slaves throughout Spanish America is amply attested, as are the attempts by adult Africans to speak Spanish. Despite hundreds of literary and folkloric documents describing the halting Spanish of Africans in Argentina, Uruguay, Peru, Bolivia, Colombia, Mexico, and Central America, these populations remained largely in rural areas (originally working in mining and later in plantation agriculture), and their speech had little effect on urban language. Only when Africans and their immediate descendents moved to cities (to work as servants, laborers, and, once freed, as artisans and entrepreneurs) was it possible for their language to be heard, and to exert a slight but palpable influence on the surrounding Spanish dialects. Thus for 
example in nineteenth century Buenos Aires and Montevideo, where the African population at times reached more than $30 \%$, Americanborn Africans spoke Spanish natively, but African born bozales, as they were called, still evidenced the traits of the second-language learner. In the cities, many of these bozales worked as street vendors, crying out their wares in distinctive songs or pregones, and their approximations to Spanish were often imitated in popular culture; thus the Africanized realization of escoba as shicoba was imitated by white songwriters and poets, representing the black shicobero or itinerant broom-vender. Similarly, the tango, now a highly formalized European dance, was once the exclusive purview of Africans in Buenos Aires, and the tango de negros was the equivalent of the juke joint in the United States. Forbidden by social taboos from openly socializing with Africans, young white residents of Buenos Aires would disguise themselves and slip to the edges of town in order to participate in the Africanized dances and songs. The tendency to introduce popular language into the words of tangos originally involved African contributions, only later turning to the Italian-derived lunfardo spoken by Italian immigrants in the port of Buenos Aires (Lipski a). African vocabulary items became implanted in Argentine and Uruguayan Spanish, the most common being mucama 'female domestic servant,' coming from the kiMbundu word (spoken in Angola) meaning female attendant of a queen (this is similar to Spanish azafata 'airline hostess,' originally an Arab word referring to a female court servant). The formerly popular Argentine dance milonga is also derived from an African word, as are other more local words. In the Caribbean, the African population was largely concentrated in rural plantations, especially in Cuba, and although dozens of authors imitated their bozal speech, it had no impact on Caribbean Spanish until freed Africans moved to the cities and their speech and music were absorbed by rebellious youth, always eager for novelty and iconoclastic behavior. Ultimately, the overwhelming torrent of African words and even some grammatical patterns became entrenched in the popular imagination (including the quintessentially Caribbean word chévere 'great, fantastic' as well as the modern Cuban asere 'friend'), using the centrifugal force of urban speech and, later, the potent international outreach of recorded music, to spread Afro-Cuban language to those with no African heritage.

In wealthier families, black servants cared for children. The white children learned the language of their black caretakers and their children, and as occurred in the southern United States, grew up in effect bi-dialectal. Finally, as the popular music of Afro-Hispanic groups caught on with middle-class youth, words and expressions originally reserved for speakers of African descent became part of popular culture. The Argentine tango was once the exclusive purview 
of black residents (who formed $30 \%-40 \%$ of the population of Buenos Aires and Montevideo at the time of colonial independence), the same as the Veracruz jorocho, the Cuban son, the Dominican merengue, the Colombian cumbia, the Peruvian marinera, and the Puerto Rican bomba and plena. As this music became accessible to wider segments of the population, the remnants of Afro-Hispanic language found in the earliest musical forms also lost their ethnic designations.

Finally, several hundred thousand Chinese laborers arrived in Cuba, Peru, and other Latin American countries in the second half of the nineteenth century, and originally worked in plantation agriculture alongside former African slaves, often learning Spanish from Africanborn bozales (Lipski 1998, 1999b). Their curious approximations to Spanish went unnoticed until they moved from the plantations to the cities, becoming merchants and shop-owners, at which point the habla de chino became a staple of Cuban life, and Chinese-Spanish linguistic and cultural hybrids entered the language (Varela 1980). In order to more fully appreciate the importance of cities in dialect formation, one must pay close attention to the demographic upheavals and growth patterns characteristic of cities and speech communities in Spain and Spanish America over a period of nearly five centuries.

\section{Cities in Spain and Spanish America: growth and development}

For at least two centuries, Spanish settlement of the New World was planned in Castile, engineered in Andalusia, and aided by the Canary Islands. Administrative matters involving the American colonies were handled by the Consejo de Indias, in Madrid. Future settlers made application for passage at the Casa de la Contratación in Seville, and often waited a year or more before embarking for Spanish America. The Consulado de Sevilla, dominated by Sevillian merchants, long enjoyed a monopoly on trade with the Americas. Ships' crews were recruited from Andalusia and the Canary Islands. Many ships left directly from Seville; others departed from the Andalusian ports of Cadiz, San Lucar and Huelva. Ships picked up supplies and refitted at the Canary Islands, and sailed to a small number of authorized American ports, in order to maintain the royal trade monopoly. Pirate attacks also spurred creation of the fleet system, wherein armed convoys of ships traveled together between Spain and the Americas. Once in the Caribbean, some ships would break from the convoy to trade with smaller ports, and illicit trade also resulted in unscheduled port calls, but the majority of Hispano-American contact followed welldelimited paths. Prevailing winds and sea currents, as well as partially fortuitous Spanish colonizing patterns, shaped preferential routes into and out of the Caribbean. Ships arriving from Spain entered the southern Caribbean, often stopping at Jamaica or another eastern 
island, and docked at Cartagena de Indias, which became the major South American port and trade zone. Other ports were established along the Colombian and Venezuelan coast, among them Santa Marta, Riohacha, Cumana, Maracaibo, and La Guaira, but none rivaled Cartagena. Ships carrying goods and passengers bound for the Pacific coast of South America put in at Portobelo, Panama, whence cargo was transferred to Panama City on the Pacific side by a combination of mule trains and river boats. Guayaquil and El Callao were the major Pacific ports, and once Spain began sending galleons to the Philippines, Acapulco was added to the list. On the Caribbean coast of Mesoamerica, Veracruz was the main point of entry, while smaller ports in Central America, particularly Trujillo and Puerto Caballos (modern Puerto Cortes) in Honduras handled occasional traffic. Ships returning to Spain from Portobelo usually put in again at Cartagena, then headed for the northern Caribbean. Havana became the foremost port of supply for returning ships, while other Caribbean towns such as Santo Domingo, the first Spanish city in the Americas, quickly lost their early importance.

Except for a few of the earliest towns such as Nombre de Dios and Portobelo, which were quickly abandoned in the Spanish colonial scheme, the hubs of Spanish colonial society have evolved into large urban masses. Mexico City is in the running for the world's largest city; Bogota, Caracas, Santiago, Buenos Aires, and Lima each boast several million inhabitants; Panama City, Guayaquil, Havana, Montevideo, Acapulco, San Juan somewhat less; Cartagena, Santo Domingo, Quito, La Paz, Asuncion, Veracruz, Cochabamba, Tegucigalpa, San Salvador and Managua are also major metropolitan areas. In Spain, Seville has more than a million inhabitants, Madrid has more than twice that number, and Cadiz, Huelva and La Coruña have several hundred thousand each. Each city is a complex sociolinguistic microcosm, and it is difficult to imagine how any external linguistic force could have a significant impact on the thriving Spanish dialects. The notion that the idiosyncracies of a literal handful of people, no matter how rich or powerful, could permanently transform the speech of an entire city, region, or nation lies beyond belief. Aside from the internal dynamics of large urban areas, the only major linguistic shifts occurring in modern Latin America result from rural migration to the cities.

Matters were not always as they are today; the explosive demographic growth that has turned former colonial centers into impersonal urban sprawls has occurred within the past century or less (cf. Sánchez Albornoz 1974). During the time when the foundations for Latin American dialects were laid, the major cities and towns were a tiny fraction of their present size, and models of language change 
unthinkable today were viable options in past centuries. Moreover, the population did not always increase across time; the Spanish colonies were afflicted with epidemics and plagues that sometimes reduced the population of a given area by half or more. As a result, some cities experienced no net growth over a period as long as two centuries. The relatively small size of colonial Latin American cities, and the consequent likelihood that new arrivals could affect speech patterns, can be seen by considering some representative population figures:

Cartagena de Indias was, for much of the colonial period, the principal port of entry for what is now Colombia, as well as an obligatory stopover for ships going to Panama, with shipments bound for Peru, Acapulco or the Philippines. At the beginning of the seventeenth century, Cartagena had some 2500 free inhabitants. The population rose considerably during that century, but following repeated pirate attacks, the population of Cartagena at the beginning of the eighteenth century again reached a low of some 2500 free inhabitants, plus an undetermined but large number of African slaves. By way of comparison, Seville then had some 80,000 inhabitants, having lost almost as many in earlier decades through the plague. Madrid was approximately twice the size of Seville. By the middle of the seventeenth century, Potosí, Bolivia grew to more than 150,000 inhabitants, momentarily becoming the largest city in Spanish America, although this growth was as transitory as it was meteoric.

Nombre de Dios, Panama's first port, never boasted a stable population of more than a hundred free adult residents, and often subsisted with a few dozen vecinos (male heads of household). During the heyday of the Spanish fleet stopovers, the crucially important town of Portobelo had only a few hundred residents for most of the year, although during the annual feria the population temporarily rose to several thousand. Panama City, a major Pacific port, had only 5,000 inhabitants as late as 1850 . Three hundred years earlier, the city had the same population, which never rose higher than 8,000 at any point during colonial history (Jaén Suárez 1978). By the end of the century the population had risen to some 25,000. In 1911, the height of the Panama Canal construction boom, Panama City boasted more than 46,000 residents. Today it has more than two million inhabitants.

At the beginning of the seventeenth century, Caracas had some 500 white residents out of a total of slightly more than 3,000 . By 1770 , the total population had risen to nearly 19,000 , and by the beginning of the nineteenth century Caracas had 42,000 inhabitants. Today its population is more than two million. Quito in 1779 had approximately 25,000 residents. In 1857 , the total had risen to only 36,000 , and by the early twentieth century, the total population was around 50,000. Its 
current population is approaching one million. The population of Santiago, Chile, was estimated at 28,000 in 1744, at 69,000 in 1813, and at 98,000 in 1835. Lima, Peru, had a total population of around 90,000 as late as 1836 , which approximately doubled by the end of the nineteenth century. The twentieth century has seen Lima grow from a city of 200,000 to a metropolis of more than six million residents. At the time of independence, Mexico City, today the world's largest metropolis, was home to scarcely more than 100,000 residents, and during the colonial period its population was much smaller. At the same point, Veracruz had perhaps 5,000 residents, Guanajuato 35,000, Mérida 30,000, and Zacatecas 26,000. Buenos Aires, one of the largest cities of Latin America, had little more than 20,000 residents in the final decades of the eighteenth century. The city had only 40,000 residents in 1810 , at the dawn of colonial independence. By 1869, the population had risen to 187,000; in 1895 the figure had exploded to 650,000 , and by 1914 a million and a half people lived in Buenos Aires. Figures for Montevideo are comparable. Founded in 1726, the city had 10,000 inhabitants by the 1781 census. By 1843 , the population had risen to only 31,000 . A century later, Montevideo had more than half a million residents; today it has more than a million. In a series of censuses taken beginning in 1790, Havana had some 51,000 inhabitants, a number which rose to 84,000 in 1817. Potosi had dropped to 22,000 residents, Bogota had 21,000, Guatemala City fewer than 25,000, and San Salvador only 12,000.

The importance of these population figures is obvious upon consideration of the proposed formative periods of Latin American Spanish. If the 'Antillean' period prior to 1530 is considered crucial, then only a handful of island villages with a total population of a few thousand colonists are at stake. If the entire sixteenth century is taken into account, few cities in Spanish America achieved a population of 5,000 or more inhabitants. Some of today's major population centers, embodying national dialects, had not yet been founded. When one considers that a typical fleet arriving at Cartagena, Portobelo, or Lima might bring several hundred settlers, the possible linguistic effects of a contingent of new settlers on an evolving dialect could be considerable. A single fleet could, under some circumstances, bring new arrivals who amounted to nearly half the resident population, and even if not all new settlers remained in the port of entry, their linguistic contributions would not be inconsequential.

By the end of the seventeenth century, some cities in Spanish America had populations ranging in the tens of thousands, not counting African slaves and non-Hispanized Indians, who often outnumbered the population of European descent. Africans and Indians, while definitely influencing the evolving speech patterns, were 
not in a position to exert the same force on urban speech patterns as the arrival of new settlers had done in the past. Only with large scale Spanish/Canary Island immigration in the latter portions of the nineteenth century did the demographic proportions of new immigrants assume a prominence similar to that of the formative period of Latin American Spanish.

\section{The changing linguistic role of growing cities}

Until at least the middle of the eighteenth century, the principal cities of Spanish America were small and relatively isolated, and contained speech patterns which could be easily influenced by rather small numbers of incoming settlers and immigrants. By comparing linguistic innovations occurring in Spain since the early sixteenth century with emerging traits of Latin American Spanish, it is possible to identify with some accuracy the period in which Latin American dialects ceased to reflect major innovations occurring in Spain:

- NEUTRALIZATION OF /b/ AND /v/: occurred in Spain from 1525 to1550; occurred in all Latin American Spanish dialects.

- DEVOICING OF VOICED SIBILANTS /z/, /dz/, and /ñn/: occurred in Spain from 1550 (Castile) to 1575+ (Andalusia); also occurred in all Latin American Spanish dialects.

- BACKING OF /š/ TO /x/: occurred in Spain from1575 to 1600; occurred in all Latin American dialects (although leaving occasional residues, such as the word chicano from the old pronunciation of mexicano with [̌̌]).

- SHIFT OF /s/ TO /2/: occurred in Castile from 1625 to 1675; did not occur in any Latin American Spanish dialect, although successive waves of Spanish immigrants kept the sound alive in immigrant neighborhoods and families, and some educated Latin Americans affected this pronunciation at least through the nineteenth century (Guitarte 1973).

- SHIFT OF VELAR /s/ TO UVULAR /P/: occurred in Castile after 1700; did not occur anywhere in Latin America.

- ASPIRATION/LOSS OF FINAL /s/: occurred massively in Andalusia after 1700, although the process was begun well before. This pronunciation is found in areas of Latin America that maintained sustained contact with Andalusia and the Canary Islands (the Caribbean and coastal areas of South America), but did not reach inland areas in which the early Andalusian presence was subsequently diluted by arrivals from other areas of Spain and by the local Spanish dialects.

- LOSS OF SUBJECT PRONOUN vos: occurred in Spain sometime after 1700 , yet this change did not reach all areas of 
Latin America but only those colonies and cities with the heaviest sustained contact with Spain.

None of the above changes occurred in Sephardic Spanish, truncated from the Iberian Peninsula towards the turn of the sixteenth century, thus reinforcing the notion that the first half century of Spanish taken to the Americas did not form the basis for subsequent dialect evolution as suggested by the 'founder principle.' These comparative data suggest that by around 1700, regional Latin American varieties of Spanish had developed enough critical mass to successfully resist the wholescale imitation of innovations coming from Spain. One possible counterexample is the innovative pronouns usted/ustedes, which became solidified in Spain towards the end of the seventeenth century, but which are found in all Latin American dialects (but not in Sephardic Spanish). It is clear that although these pronouns did not fully triumph in written literary usage until nearly 1700 , they had been used in spoken Spanish for at least a century prior to that time, and were amply known and used in Spanish America.

\section{Later extraterritorial influences on Latin American Spanish}

In 1700 , the major cities of Spanish America had populations ranging from 5,000 to nearly 50,000, with the average around 15,000 . Given the inter-colonial isolation resulting from Spanish monopolistic trade and immigration practices, strong capital city-based regional dialects were already forming. However, although language innovations arriving from Spain had an increasingly smaller impact on Spanish American dialects (possibly due to the rather gradual arrival of Spanish colonists across time and space), the cities were still small enough to feel the linguistic effects of subsequent demographic shifts, while not yet large enough to dominate the speech of the hinterlands. Indeed, several post-eighteenth century migratory patterns exerted significant and permanent influences on regional varieties of Spanish. Among the most noteworthy are:

- The arrival of tens of hundreds of thousands of Italian immigrants in Buenos Aires and Montevideo beginning towards the end of the nineteenth century completely transformed the phonetic and lexical patterns of Rio Platense Spanish. To give an idea of the magnitude of this immigration, nearly 2.3 million Italians emigrated to Argentina alone between 1861 and 1920, with more than half arriving after 1900 and making up nearly $60 \%$ of all immigration to Argentina. Most of the immigrants ended up in greater Buenos Aires (Bailey 1999:54), and made up between $20 \%$ and $30 \%$ of that city's population. As a result of immigration, largely by Italians, the population of greater 
Buenos Aires (including the surrounding countryside) grew from 400,000 in 1854 to 526,500 in 1881 and to 921,000 in 1895 (Nascimbene 1988:11).

- Canary Island immigration to the Americas had always been significant, since the Spanish government used the economically-stressed Canary Islanders to settle undesirable areas or contested frontiers (e.g. in eastern Louisiana, along the French-Spanish border of the island of Hispaniola, which is now the Haitian-Dominican border, and the foundation of Montevideo in 1726 by Canary Islanders, to head off Portuguese incursions across the Rio Plata estuary from Buenos Aires). It was, however, the massive immigration of Canary Islanders to Cuba in the late nineteenth and early twentieth centuries that left the deepest Canary Spanish footprint, to the extent that Cubans and Canary Islanders frequently mistake one another for compatriots when meeting for the first time. Originally working in the countryside, Canary Islanders-or isleños, as the Cubans called them-eventually moved to the cities, comprising nearly $25 \%$ of the Cuban population around the turn of the twentieth century. During the first half of the twentieth century a huge Canary Island contingent arrived in Venezuela, and brought many regional traits to that country which, like Cuba, already spoke a dialect similar to that of southern Spain and the Canary Islands. Canary Islanders also arrived in large numbers in Argentina, but the Italian presence in Rio Platense Spanish was so strong that little Canary Island linguistic impact was felt, except for some vocabulary items such as pibe, 'young man.' Accurate figures for immigrants during the nineteenth century do not exist, but an approximate picture can be reconstructed (Hernández García 1981). For example, in the twenty-year period from 1818-1838 more than 18,000 islanders emigrated to the Americas, most to Cuba and proportionately fewer to Venezuela and Puerto Rico. In the half century from 1840 to 1890 , as many as 40,000 Canary Islanders emigrated to Venezuela alone. In the period from 1835 to 1850 , more than 16,000 islanders emigrated to Cuba, a rate of approximately 1,000 per year. In the 1860 's, Canary emigration to the Americas took place at the rate of over 2,000 per year, at a time when the total islands' population was perhaps 240,000 . In the two-year period 1885-6, more than 4,500 Canarians emigrated to Spanish possessions (including the Philippines and Fernando Poo), of which almost 4,100 went to Cuba and 150 to Puerto Rico. During the same time period, some 760 Canary Islanders emigrated to Latin American republics, with 550 going to Argentina and Uruguay and more than 100 to 
Venezuela. By the period 1891-1895, Canary emigration to Argentina and Uruguay was slightly more than 400,600 to Puerto Rico, more than 2,000 to Venezuela, and more than 17,000 to Cuba. By comparison, in the same half century or so, emigration to Cuba from other regions of Spain included: 14,000 from Barcelona, 18,000 from Asturias, and more then 57,000 from Galicia. During the same period more than 18,000 Galicians arrived in Argentina and Uruguay, but only a handful arrived in Venezuela.

- By far the largest extra-Hispanic demographic and linguistic influence to reach Latin America was carried by the hundreds of thousands of African slaves who for nearly four centuries provided much of the labor force in colonial and post-colonial Spanish America. Although African lexical items entered several regional Spanish dialects, in the Caribbean, the Southern Cone, and even Mexico, the original large African populations were concentrated in rural regions, and left little lasting influence on the Spanish language. Matters changed rapidly in the Spanish Caribbean following the Haitian revolution, which began in 1791. The French half of the island of Hispaniola, known as Saint-Domingue, was by far the world's largest sugar producer at the end of the eighteenth century, and the ratio of black slaves to white masters was as high as 100:1 on some plantations. Following the revolution and the establishment of the free nation of Haiti by the 1820's, sugar production dropped almost to zero, and other Latin American countries which had previously been reluctant to compete against the French near-monopoly rushed to fill the gap. This required the immediate importation of hundreds of thousands of additional laborers, the majority of whom came directly from Africa, with a considerable number also drawn from other established Caribbean colonies. The two largest participants in the new sugar boom were Brazil and Cuba. To give an idea of the explosive growth of the African population, up until 1761, approximately 60,000 African slaves had been taken to Cuba. Between 1762 and 1780 some 20,000 more slaves were imported. From 1780 to 1820 the number jumped dramatically: more than 310,000 African bozales arrived during this period, bringing the total number of slaves taken between the first colonization and 1820 -the beginning of the sugar boom- to approximately 390,000 . By 1861 , this number had jumped again to an astonishing 849,000 , which means that nearly $86 \%$ of all slaves taken to Cuba arrived during the first half of the nineteenth century. Extrapolating to allow for underreporting and clandestine traffic, some historians estimate a total as high as 1.3 million African bozales taken to Cuba during the entire 
slave trade. Puerto Rico also participated in the explosive growth of sugar plantations, although on a proportionally smaller scale. Out of a total of 75,000 African slaves estimated to have arrived in Puerto Rico during the colonial period, almost 60,000 arrived in the late eighteenth and early nineteenth centuries. Among other Spanish American colonies which saw rapid growth of the African-born population that met the new agricultural production demands were Venezuela (principally the production of cacao, which had started in the seventeenth century) and Peru (cotton and sugar cane). Following the abolition of slavery in the second half of the nineteenth century, many former slaves moved to urban areas, where their speech patterns gradually influenced the lowest sociolinguistic strata, and ultimately percolated up to provide vocabulary items and possibly even subtle pronunciation variants to the Spanish Caribbean population as a whole.

- Also arriving in Cuba, Puerto Rico, and the Dominican Republic following the abolition of slavery, were tens of thousands of contract laborers from other Caribbean islands who already spoke Afro-European creoles, some of which bore striking resemblances to colloquial Caribbean Spanish. Speakers of Papiamentu, a Spanish-Portuguese derived creole from the Dutch slaving island of Curaçao, arrived in large numbers in Cuba and Puerto Rico; in the latter country Papiamentu songs and poems have survived. Haitian Creole speakers have always interacted with speakers of Dominican Spanish, and although Dominicans are reluctant to admit any influence, popular Dominican Spanish contains demonstrable Haitian traces (Lipski 1994). Thousands of Haitians also worked as contract laborers in Cuba (they continue to do so even today), and figure in such literary works as Alejo Carpentier's Ecué yamba-o. Jamaican creole English speakers also worked in Cuba and continue to constitute a major part of the Dominican labor force. Although these creole-speaking laborers largely worked in rural settings, they did exert a cumulative effect on local varieties of Spanish, and arguably reinforced Caribbean Spanish tendencies such as non-inverted questions, infinitives with explicit subjects, and the heavy use of redundant subject pronouns, since all the above-mentioned creole languages also share these traits.

\section{The final stage: the cities fight back}

As witnessed by the population figures cited earlier, the principal cities of Latin America continued a steady but slow growth pattern until the end of the nineteenth century, while the twentieth century brought 
explosive demographic growth, with urban populations often increasing by several orders of magnitude in less than a century. The growth of cities was fueled by a combination of decreased mortality rates, naturally exponential population growth, and especially in recent decades, the massive migration from rural areas to urban centers. At the same time, mass media have become ever more effective in reaching even the most isolated rural residents; battery-powered radios can be found in the jungles, mountaintops, and tiny villages of Latin America, and television is reaching ever larger numbers of citizens. Literacy campaigns and the frequent practice of requiring newly graduated teachers to perform a 'public service' stint in a remote area have also conspired to bring the speech patterns of large cities to rural inhabitants, with the result that regional and local forms of Spanish are being rapidly displaced by a pan-urban prestige standard which, while not always imitated perfectly by those not living in cities, represents a powerful attractive force.

- This urbanization of regional and local varieties of Spanish is nowhere more dramatically visible than in Mexico, where little more than half a century ago distinctly Caribbean forms of Spanish could be heard in Veracruz and Tabasco, strongly Central American varieties (including widespread use of vos) were found throughout Chiapas, the Acapulco dialect bore a striking resemblance to the Pacific coast of South America, and other strikingly original dialects were found in Baja California, Campeche, in the Afro-Mexican villages of Oaxaca and Guerrero, among other places. For example, today, as witnessed by the Atlas lingüístico de México (Lope Blanch 1990), most of these regional varieties have been almost totally supplanted by a pan-Mexican language which bears the unmistakable profile of Mexico City, Guadalajara, and other large inland cities. Traces of the originally diverse Mexican dialect mosaic can be regularly found only in remote Yucatan and among the most marginalized rural residents of peripheral portions of the country.

- Argentina is another vast nation that has traditionally exhibited considerable dialect variation, particularly in pronunciation (Vidal de Battini 1964a, 1964b; Canfield 1981). At one point, the pronunciation of $/ y /$ as [ž] or [̌̌] was limited to Buenos Aires and surrounding provinces, while the same sound was afforded to the trill /rr/ in other areas to the north and west of Buenos Aires. So powerful has the Buenos Aires prestige standard become-propagated by radio, television, school teachers from the Buenos Aires area, and increased travel opportunities-that the Buenos Aires pronunciation is extending throughout the nation, replacing many regional dialects and resulting in a 
national speech profile which is much more homogeneous than it was only fifty years ago.

- Even tiny Puerto Rico once contained considerable dialect diversity, particularly regarding the pronunciation of $/ \mathrm{l} /, / \mathrm{r} /$, and /rr/ (Navarro Tomás 1948), but the speech of this nation has been homogenized to fit the San Juan standard, with only a slight rural-urban distinction and some variation correlated with educational level.

- In Venezuela, the traditional speech of the Andean highlands, once sharply different from Caracas, Maracaibo, and other coastal cities, has now almost completely disappeared, replaced by close approximations to Caracas speech (e.g. Longmire 1976, Márquez Carrero 1985, Alvarez et al. 1992, Obediente 1998).

- As a counterpart to the leveling influences of major urban dialects, a few Latin American nations still contain enough geographical and communication barriers as to allow for considerable regional dialect differentiation, in which the speech of major cities exerts little influence on a national scale. Honduras (small but extremely mountainous and with very difficult communications) and Bolivia (larger and with the same problems) come readily to mind in this respect.

- Finally, we must also mention the case of Spain, where as recently as forty years ago the nation was a mosaic of widely varying regional dialects which had tenaciously resisted effacement for hundreds of years. Today, given mass communication, excellent travel opportunities, and, for men, obligatory military service, most of the dialects described in the dozens of monographs on Spanish regional speech reside only in the speech of elderly rural residents, and will disappear within the next twenty years.

\section{Conclusions}

The preceding remarks, by necessity sketchy, approximate, and extremely compressed, underscore the crucial role of urban centers in channeling the development, diversification, and reunification of the Spanish language in Latin America as well as in Spain. Without detracting from the importance of rural areas and peoples, it is no exaggeration to state that modern Latin American Spanish is the end product of cities' dramatic channeling influences over the past several centuries. As rural migration to cities continues unabated in Latin America, and as cities in Spain become the linguistic centers of newly autonomous regions, it is only logical to expect even further linguistic consequences of the urbanization of Spanish. The preceding 
discussion is but a first chapter in what must surely be a very interesting saga in times to come.

\section{Notes}

1 When referring to the 'Andalusian' character of modern Latin American Spanish, this can only refer to the western Andalusian provinces of Seville, Cádiz, and Huelva, the areas of Andalusia from which most of the original colonists emigrated. Even today these regions do not distinguish /s/ and /2/ (although in rural regions [2] is the preferred pronunciation for all sibilants), they strongly prefer ustedes to vosotros (although the latter pronoun is making inroads due to urban prestige standards from other areas of Spain), and exhibit alveolar /s/. In the remaining areas of Andalusia, the more 'Castilian' traits of vosotros, distinction of /s/-/2/, and apicoalveolar /s/ prevail. Yeísmo (the neutralization of $/ y /$ and $/ 8 /$ in favor of the former phoneme) is often mentioned as an 'Andalusian' trait, but this pronunciation characterizes most of Spain, while some pockets in Andalusia and even more in the Canary Islands still retain /8/, as do several Latin American dialects. Thus, in the balance, it is fair to describe Latin American Spanish in the aggregate as 'non-Castilian' rather than 'Andalusian,' with specific reference to the lack of /2/ and vosotros throughout Latin America.

\section{Works Cited}

Alvarez, Alexandra, et al. 1992. El idioma español de la Venezuela actual. Caracas: Lagoven.

Bailey, Samuel. 1999. Immigrants in the lands of promise: Italians in Buenos Aires and New York City, 1870-1914. Ithaca: Cornell University Press.

Boyd-Bowman, Peter. 1956. Regional origins of the earliest Spanish colonists of America. PMLA 71.1152-1172.

---. 1975. A sample of sixteenth century 'Caribbean' Spanish phonology. 1974 Colloquium on Spanish and Portuguese linguistics, ed. by W. Milan, J. Staczek, and J. Zamora, 1-11. Washington: Georgetown University Press.

Canfield, D. Lincoln. 1981. Spanish pronunciation in the Americas. Chicago: University of Chicago Press.

Catalán. Diego. 1956-7 . El çeçeo-zezeo al comenzar la expansión atlántica de Castilla. Boletim de Filologia 16.306-334, ---. 1957. The end of the phoneme /z/ in Spanish. Word 13.283-322. 
---. 1958. Génesis del español atlántico (ondas varias a través del océano). Revista de Historia Canaria 24.233-242.

Frago García, J. 1983. Materiales para la historia de la aspiración de la /-s/ implosiva en las hablas andaluzas. Lingüística Española Actual 5.153-171.

Granda, Germán de. 1979. Factores determinantes de la preservación del fonema /ll/ en el español del Paraguay. Lingüística Española Actual 1.403-412.

Guitarte, Guillermo. 1973. Seseo y distinción s-z en América durante el siglo XIX. Romanica 6.59-76.

---. 1980. Para una periodización de la historia del español de América. Perspectivas de la investigación lingüística hispanoamericana, ed. by Juan Lope Blanch, 119-137. Mexico: Universidad Nacional Autónoma de México, 1980.

Hernández García, Julio. 1981. La emigración de las Islas Canarias en el siglo XIX. Las Palmas: Excmo. Cabildo Insular de Gran Canaria.

Jaén Suárez, Omar. 1978. La población del istmo de Panamá del siglo XVI al siglo XX. Panama City: Impresora de "La Nación."

Lapesa, Rafael. 1980. Historia de la lengua española. Madrid: Gredos, 8th ed.

Lipski, John. 1994. A new perspective on Afro-Dominican Spanish: the Haitian contribution. Research Paper No. 26, University of New Mexico Latin American Institute. ---. 1995. Literary 'Africanized' Spanish as a research tool: dating consonant reduction. Romance Philology 49.130-167.

---. 1996. Contactos de criollos en el Caribe hispánico: contribuciones al español bozal. América Negra 11.31-60.

--- 1998. El español de los braceros chinos y la problemática del lenguaje bozal. Montalbán 31.101-139.

---. 1999a. Creole-to-creole contacts in the Spanish Caribbean: the genesis of Afro Hispanic language. Publications of the Afro-Latin American Research Association (PALARA) 3.5-46. ---. 1999b. Chinese-Cuban pidgin Spanish: implications for the Afrocreole debate. Creole Genesis, attitudes and discourse, ed. by John Rickford and Suzanne Romaine, 215-233. Amsterdam: John Benjamins.

---. Forthcoming. Panorama del lenguaje afrorrioplatense: vías de evolución fonética. Anuario de Lingüstica Hispánica. 
Lockhart, James and Stuart Schwartz. 1983. Early Latin America. Cambridge: Cambridge University Press.

Longmire, Beverly. 1976. The relationship of variables in Venezuelan Spanish to historical sound changes in Latin and the Romance languages. Ph. D. dissertation, Georgetown University.

Lope Blanch, Juan, ed. 1990. Atlas lingüístico de México, vol. I. Mexico City: Colegio de México/Fondo de Cultura Económica.

Márquez Carrero, Andrés. 1985. Geografía lingüística del Estado Mérida. Mérida: Universidad de los Andes.

Mufwene, Salikoko. 1996a. The founder principle in creole genesis. Diachronica 13.83-134.

---. 1996b. Creole genesis: a population genetics perspective.

Caribbean languages old and new, ed. By Pauline Christie, 163-196. Kingston, Jamaica: The Press University of the West Indies.

Nascimbene, Mario. 1988. Los italianos y la integración nacional. Buenos Aires: Ediciones Selección Editorial.

Navarro Tomás, Tomás. 1948. El español en Puerto Rico. Río Piedras: Editorial Universitaria.

Obediente, Enrique, ed. 1998. El habla rural de la Cordillera de Mérida. Mérida: Universidad de los Andes.

Rosenblat, Angel. 1977. Los conquistadores y su lengua. Caracas: Universidad Central de Venezuela.

Sánchez-Albornoz, Nicolás. 1974. The population of Latin America. Berkeley: University of California Press.

Torreblanca, Máximo. 1989. La /s/ implosiva en español: sobre las fechas de su aspiración. Thesaurus 44.281-303.

Varela, Beatriz. 1980. Lo chino en el habla cubana. Miami: Ediciones Universal, 1980.

Vidal de Battini, Berta. 1964a. El español de la Argentina. Buenos Aires: Consejo Nacional de Educación.

---. 1964b. El español de la Argentina. Presente y futuro de la lengua española, t. I, 183-192. Madrid: Cultura Hispánica. 